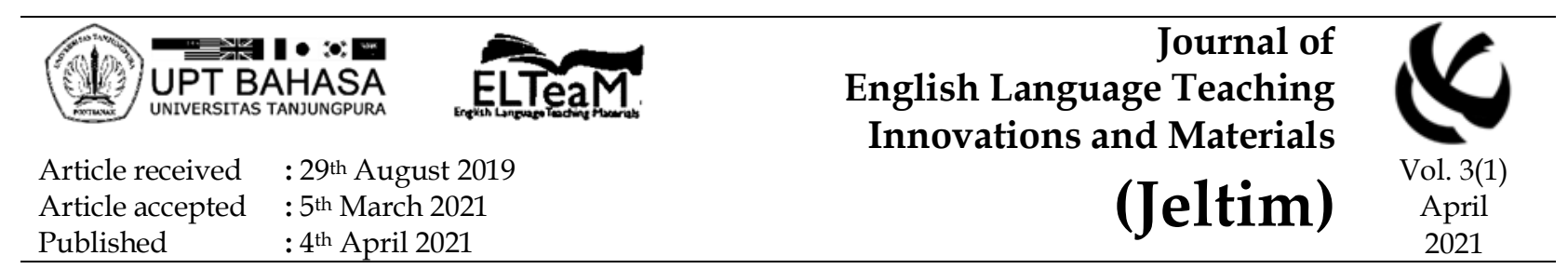

\title{
Low proficiency students: can we help them to speak confidently?
}

Muriatul Khusmah Musa 1, Rushita Ismail 2,

1Akademi Pengajian Bahasa, Universiti Teknologi MARA Cawangan Pulau Pinang,

Pulau Pinang, Malaysia

muriatul557@uitm.edu.my

${ }^{2}$ Akademi Pengajian Bahasa, Universiti Teknologi MARA Cawangan Pulau Pinang,

Pulau Pinang, Malaysia

rushita@uitm.edu.my

\section{DOI: http://dx.doi.org/10.26418/jeltim.v3i1.34964}

\begin{abstract}
This action research was carried out to find out whether the speaking activities that were done during English lessons could encourage the low proficiency students to speak English confidently. These students admitted that they were afraid of speaking English, particularly in front of their classmates. They had very low self- confidence and felt very anxious when they were asked to speak or present in English. For this research, five speaking tasks were incorporated in the English class with the aim of building up students' confidence and at the same time encouraging them to speak and participate in the English speaking activities. The five tasks were: self- introduction, fairy tale role-play, open mic, product advertisement campaign and group decision making. These activities were carried out individually as well as in small groups. In short, all the students were given an equal chance to speak English and actively participate as individuals and as group members. Students' positive responses signify the speaking tasks have helped to reduce their speaking anxiety, build up their confidence in speaking English and improve their speaking skills.
\end{abstract}

Keywords: low proficiency, anxious, participate, confidence, encourage

How to cite this paper: Muriatul Khusmah Musa \& Rushita Ismail. (2021). Low proficiency students: can we help them to speak confidently? Journal of English Language Teaching Innovations and Materials (Jeltim), 3(1), pages. DOI: http://dx.doi.org/10.26418/jeltim.v3i1.34964 
This action research was carried out with the aim to find out whether the speaking activities that were carried out in the English language class would be able to increase students' confidence in speaking English and at the same time lower down their feeling of anxiety whenever they were asked to speak English, especially in front of the class. The students who were involved in the action research were 11 students from the second semester of pre-diploma programme in Universiti Teknologi MARA (UiTM), Cawangan Pulau Pinang Malaysia. The pre-diploma programme is a special preparation program for students from low income families who are not qualified to directly enrol into any diploma programmes in UiTM due to their poor academic achievement in Malaysian Certificate of Education or Sijil Pelajaran Malaysia (SPM). Students in this programme will go through 14 weeks of preparation class and if they pass the entrance test, they are allowed to enrol into any diploma programmes in UiTM.

For this research, the group of students was categorised as low proficiency based on the results of their English language subject in Sijil Pelajaran Malaysia (SPM) or Malaysian Certificate of Education. 7 students obtained D for the subject while another 4 got C for their SPM English. Due to their low proficiency and lack of exposure to English, these students were shy and anxious whenever they were asked to speak English. During the first lesson when the students were asked to introduce themselves, they were so nervous and unable to control their anxiousness. Most of them stammered, read from their notes most of the time and had difficulty finding words in English even while introducing themselves. When asked, they admitted that they felt nervous and did not know what to say in English as they were not used to speaking in English especially in front of the class, hence, their confidence level was very low. However, these students needed to be able to speak English because they would be joining the diploma programmes in UiTM and English is the language of instruction in the university. Therefore, it was very crucial for the students to build up their confidence and be able to speak in English despite their low proficiency. With this in mind, the researchers decided to incorporate 5 speaking activities which would require the students to speak in English. The researchers believed that encouraging the students to speak English through these fun activities would expose them to the real use of English and gradually make them feel comfortable and confident to speak English.

MacIntyre \& Garder (1994) defined language learning anxiety as "a feeling of tension, apprehension and nervousness associated with a situation of learning a foreign language" (p. 284 ). Therefore, it is obvious that in learning a language, emotional factors such as motivation, attitudes, beliefs and anxiety may cause many difficulties to the learners. For instance, when learners feel that their English is not good, indirectly they will feel shy, nervous and apprehensive whenever they have to speak in English. Low proficiency students are those who usually face this kind of problem. This is because they 
usually have lower ability in learning a language and are weak in all the important aspects of language learning such as grammar, pronunciation, writing and speaking. Most of them have very low self-confidence and high anxiety when they are asked to speak in front of the class because they are worried about making mistakes and at the same time afraid of people's negative evaluation (Musa, et.al. 2013). Thus, many refused to speak or participate in class discussions. At the same time, low proficiency students with high level of language anxiety may also face other related problems with "self-esteem, self -confidence, and risk-taking ability, and ultimately hamper proficiency in the second language" (Crookall \& Oxford, 1991, p.52 ). According to Pakpahan, Ikhsanudin \& Sada (2017), students' inclination towards speaking in English is strongly influenced by four major factors: linguistics, psycholinguistics, cultural and institutional factors. However, their study on students' willingness to speak English in campus indicated that social -cultural and institutional factors overriding the other two factors. They further added that, the use of English must be made compulsory not only during English classes but also in other campus/school activities as well. This shows that students need to be forced to speak English consistently, otherwise they would not want to use the language but resort to their own mother tongue.

Therefore, it is very important to encourage the low proficiency students to speak English. This can be done by involving them in speaking activities which require them to speak and participate actively. A lot of exposure to the language will make them feel more confident in using the language and consequently lower down their language learning anxiety. However, to encourage the low proficiency students to speak, the activities that are designed for them must be interesting and within their level of proficiency. According to Sullivan (2016) most language learners preferred speaking tasks which provide them with the opportunities to talk and build relationships with the classmates and their language teachers. Some of the activities which could create interest in learning English as well as improving students' communication skills are guessing games, picture games, miming, debates, jigsaw activities, and role plays (Zhu, 2012).

However, students' cultures and environment will usually affect their learning preferences, interests as well as their perceptions on the activities chosen by their teachers (Dörnyei \& Ushioda, 2011). Even though it is not easy to decide on activities that are suitable for the students or whether the activities match with students' level of proficiency, teachers' teaching experience and knowledge about their own students can be used as the guidelines for the activities in the speaking lessons. Teachers must know how to choose appropriate activities based on what their students' like and dislike because this will lead to enjoyment in the teaching and learning process which will result in attentive participation in the class (Samperio, 2017). 
For this study, all the five activities: self introduction, fairy tale role-play, open mic, product advertising and group discussion provided authentic practices for the students similar to what was suggested by Celce-Murcia (2000) as cited in Kurniawati (2013). According to him, students need to be exposed to real use of language while in the classroom such as participating in group discussions (leading \& taking parts in discussions), interacting with their classmates and teacher, presenting ideas orally as well as asking and answering questions. Working with friends in groups can motivate students to be active participants. When students are highly motivated to participate in a group discussion they would be able to speak confidently and are not worried about making mistakes. In short, the learning process would be enjoyable as students are able to share ideas and complete the task together as a group (Maulana Ikhsanudin \& Suhartono, 2020). In addition, these activities had also provided a platform for the students to develop their confidence as well as the real life speaking skills because they were given the opportunities to communicate in different social contexts and different social roles in a safe environment, in their own classroom with their own peers. At the same time, ample preparation time and clear explanation were also given to the students. This was very important because low proficiency students would feel very anxious when they were asked to speak without any preparation in a language classroom, did not understand every word the language teacher said or even when asked to speak in front of the other students (Musa, et.al. 2013).

\section{METHOD}

This action research was carried out throughout the semester. The first activity namely, a self- introduction session was carried out during the second meeting in the first week of the semester. The second activity: folktales/fairy tales role-play was done in week 4 , open mic in week 7 , product advertising in week 10 and the discussion was in week 12. Apart from these activities, the normal classroom teaching and learning involved reading, writing, listening and grammar were also carried out. Since the number of students was small, the students were only divided into 3 groups for the group work activities.

At the end of the semester, the researchers used questionnaires to get students' feedback on the speaking activities that were carried out throughout the semester. The questionnaire was aimed to find out students' opinions on the activities, whether the activities helped to reduce their speaking anxiety and helped to improve their speaking skills. They were also asked whether the same activities should be continued with other groups of students who would be taking the course in the future. The questionnaire ended with one open-ended question asking the students whether they felt more confident to speak English after doing all the 5 speaking activities. Below are the activities which were carried out during the semester. 


\section{Self-introduction}

Students were given half an hour to prepare for the presentation. In the first part of the introduction, students were asked to introduce their name, family and talk about their hobby/hobbies. In the second part, they were asked to talk about their former school: their teachers, the subjects that they liked/disliked, their friends as well as the most unforgettable moments in school. Finally, they were asked whether they would like to send their future child/children to the school and to explain the reasons for their answers.

\section{Fairy Tale Role-play}

Students were divided into groups and were asked to choose a fairy tale/folk tale of their own choice. They were given 1 hour to prepare the dialogue/script and then to act it out in front of the class. Each group was given 15 minutes to perform.

\section{Open Mic}

Students were asked to share their experience (on anything) with the whole class. The preparation time was half an hour and the sharing session was 7-10 minutes for each student.

\section{Product Advertising}

The task required the students to imagine that they were working for an advertising agency. They were asked to design a TV advertisement for a new product such as, a new brand of shampoo, an anti-ageing cream or any new products that the groups had decided to promote. In a group of three, the students were given two hours to prepare an advertising campaign and persuade their client to commission it. They had to present the advertising poster and act out (role-play) the campaign promotion. Each group was given half an hour for the presentation.

\section{Group Discussion}

Each group was given a problem solving topic and they were required to make a decision based on the task given and present their decision to the class. During the preparation time which was carried out in the classroom, the students were allowed to refer to the internet, consulted the lecturer and discussed with friends. They were also allowed to write down notes/scripts for reference. Students were encouraged to discuss in English to promote fluency but most of the time, due to their limited vocabulary in English, the students resorted to their mother tongue. Apparently, it was easier for them to use the Malay language to express their ideas rather than searching for English words to get their meaning through. However, they were not allowed to speak Malay or read directly from the notes (they could refer to the notes if they had 
difficulties remembering the points) during the presentation/role-play. At the end of each presentation, constructive comments/feedback was given by the lecturer. It is important to give the students the feedback because a good objective feedback that is given based on facts and without any bias can be an effective tool to improve students' performance (Noor, Aman, Mustaffa \& Seong, 2010).

\section{FINDINGS}

Based on the researchers' observations, in the beginning, the students were quite shy and nervous during the first two activities. Many referred to their notes and there were times when they were literally reading from the notes that they had prepared. In many instances, some students were so nervous even to say an English word because they were afraid of making mistakes and tend to use Malay language to ask their friend/ lecturer on how they should explain something in English. Most of the time, the students would pause and code switch (from English to Malay) while doing the speaking activities. In fact, students' anxiousness was very obvious.

However, the students were more relaxed and seemed to enjoy the open mic activity. This activity provided a platform for the students to express themselves and share their experiences and thoughts. Their topics ranged from relationships, loss of the loved ones, broken friendships, disappointments in their life as well as life changing experiences that they had gone through. Surprisingly, despite making a lot of language errors and grammatical mistakes, most of the students spoke confidently without referring to or reading from their notes. This indicates that when students like and understand what they are doing, they would be able to express themselves confidently despite the language difficulties.

During the product advertising segment, the students were more prepared in explaining their products because they were allowed to continue with the preparation outside class hours. They were also creative at roleplaying the advertisement of their product. However, in certain instances, they were referring to their notes particularly when they were not sure of what to say while role playing. Perhaps this happened because unlike open mic (where students talked about something they really interested in), role-playing required the students to come up with dialogues. They were not able to talk spontaneously because they were in a made up situation (not real to them) in which they need to memorise and practise what to say. Thus, constant references to the notes were needed especially when they could not remember the lines that they had prepared.

As for group discussion and presentation segments, students were again prepared. However some were still referring to their notes even though they

Journal of English Language Teaching Innovations and Materials (Jeltim), 3(1), 1-14

Copyright (C) 2021 by Jeltim, e-ISSN 2657-1617 
were given the chance to prepare and discuss the points with their group members prior to the presentation in front of the class. Perhaps this happened because they memorised most of the dialogues lines due to lack of vocabulary (their limited linguistic ability) in English. Thus, whenever they were struggling to recall their lines, they were not able to speak spontaneously and resorted to the prepared notes.

Table 1: Students' opinions on the 5 speaking activities that were carried out in class

1. What do you think of the activities?

\#5-Very interesting 4-Interesting 3-

Undecided 2-Not Interesting 1-Not

interesting at all

a) Ice breaking

b) Fairy tales/folktales (role play)

c) Open mic

d) Product advertising

e) Group discussion

activities helped to reduce my speaking anxiety:

\#5-Strongly agree 4-Agree 3-Undecided

2-Disagree 1-Strongly Disagree

$\begin{array}{llllll}\text { a) Ice breaking } & 5 & 6 & 0 & 0 & 0 \\ \text { b) Fairy tales/folktales (role play) } & 4 & 7 & 0 & 0 & 0 \\ \text { c) Open mic } & 3 & 8 & 0 & 0 & 0 \\ \text { d) Product advertising } & 4 & 7 & 0 & 0 & 0 \\ \text { e) Group discussion } & 4 & 7 & 0 & 0 & 0\end{array}$

$\begin{array}{lllll}3 & 8 & 0 & 0 & 0\end{array}$

3. The activities helped to improve my confidence in speaking English: \#5-Strongly agree 4-Agree 3-Undecided 2-Disagree 1-Strongly Disagree

$\begin{array}{llllll}\text { a) Ice breaking } & 3 & 8 & 0 & 0 & 0 \\ \text { b) Fairy tales/folktales (role play) } & 3 & 8 & 0 & 0 & 0 \\ \text { c) Open mic } & 3 & 8 & 0 & 0 & 0 \\ \text { d) Product advertising } & 3 & 8 & 0 & 0 & 0 \\ \text { e) Group discussion } & 3 & 8 & 0 & 0 & 0\end{array}$

4. The activities helped to improve my speaking skills ( I can speak better): \#5-Strongly agree 4-Agree 3-undecided 2-Disagree 1-Strongly Disagree
a) Ice breaking
b) Fairy tales/folktales (role play)
c) Open mic
d) Product advertising
e) Group discussion $\begin{array}{lllll}1 & 8 & 2 & 0 & 0\end{array}$ $\begin{array}{lllll}1 & 8 & 2 & 0 & 0\end{array}$

$\begin{array}{lllll}1 & 8 & 2 & 0 & 0\end{array}$

$\begin{array}{lllll}1 & 9 & 1 & 0 & 0\end{array}$

$\begin{array}{lllll}1 & 9 & 1 & 0 & 0\end{array}$

$\begin{array}{lllllll}5 & 4 & 3 & 2 & 1 & \text { Total }\end{array}$

5. The activities should be continued in the future: \#5-Strongly agree 4-Agree 3-Undecided

2-Disagree 1-Strongly Disagree

$\begin{array}{lllllll}5 & 4 & 3 & 2 & 1 & \text { Total }\end{array}$



a) Ice breaking
b) Fairy tales/folktales (role play)
c) Open mic
d) Product advertising
e) Group discussion
$\begin{array}{lllll}6 & 5 & 0 & 0 & 0\end{array}$
$\begin{array}{lllll}4 & 7 & 0 & 0 & 0\end{array}$
$\begin{array}{lllll}4 & 7 & 0 & 0 & 0\end{array}$

$\begin{array}{lllll}3 & 8 & 0 & 0 & 0\end{array}$
6. I feel more confident to speak in English after doing all the activities in class.
Yes No
Total (Give reason/s for your answer)

$\begin{array}{llllll}11 & 0 & 0 & 0 & 0 & 11\end{array}$

Reasons:

\#I learn to speak English

\#I was able to do a lot of speaking practice

\#I had to speak English during the activities-felt more confident after doing the activities

\#working in small groups and knew all the people in the class- I feel confident

\#before this I was so scared to speak English because lack of practice- now more confident

\#a lot of practices- help to improve my English

\# everyone was speaking English-I feel confident

Table 1 illustrates students' feedback on the speaking activities that were carried out in the English class. The results reveal that the students were very positive about the activities that they had done. Majority admitted that the activities were interesting and had helped them to reduce their speaking anxiety, improve their confidence and speaking skills. They also agreed that these speaking activities should be retained and continued in the future. Even though there were a few students who were not sure whether these activities helped them to improve their language skills, all 11 of them agreed that they felt more confident to speak English after they had completed all the five tasks. Some of the reasons given were:

a) They learnt to speak English/had to speak English therefore they felt more confident after doing the activities.

b) Working together in small groups in which everyone they knew was speaking in English, helped them to be more confident.

c) A lot of speaking practice helped to overcome their fear, improve their English and make them feel confident to speak the language.

\section{DISCUSSION}

The objective of this research was to find out whether exposing the students to the five speaking activities, namely self- introduction, fairy tale roleplay, open mic, product advertising and group discussion would help to increase students' confidence in English, reduce their anxiousness and improve their speaking skills. Based on the students' responses in Table 1 it is clear that all the students admitted that they felt confident to speak English after completing all the five tasks. They also admitted that all the activities were 
interesting and participating in these activities helped to reduce their speaking anxiety, improve their self- confidence and speaking skills.

In this study, the development of students' self-confidence was observed through students' participation. In the beginning students were too shy to speak particularly when introducing themselves for the first time and they were still nervous during the second activity, particularly, the fairy tale role-play. However, as the lessons progressed, students' anxiousness began to reduce and their self- confidence began to build up. They were no longer shy to talk in front of the class but began to actively participate in all the activities. This was evident in the open mic, product advertising and group discussion activities. The findings are in line with the principle of "I can do it!" which was suggested by Brown (2000). According to him, one of the core principles in language learning is that learners need to believe that they are able to complete all the tasks assigned by the teacher and must be willing to speak a foreign language. This willingness to communicate in that particular language they are learning can only happen when they have self-confidence to speak. Only with this belief, students' self-confidence would surface and they would be able to motivate themselves to complete the tasks assigned to them successfully. Apart from this, the study also reveals that students' active participation and willingness to be involved in all the activities implied that they found the activities were interesting and fun. According to Sullivan (2016) speaking activities need to be within students' interest and level of proficiency and at the same time provide them with the chances to talk and connect with their friends and teachers. If the students do not find the tasks fascinating, they would be reluctant to participate. Therefore, choosing appropriate tasks for speaking class is crucial. If the students do not like the tasks, they will not be interested to participate in the class activities, thus making the teaching and learning process boring and unpleasant, thus lessen the chances for them to converse in English (Samperio, 2017).

The study also demonstrates that, in general, low proficiency students experience language anxiety, thus it is very crucial to help them overcome the anxiety and encourage them to speak in English. According to Horwitz et al (1986) it is normal for language learners to feel anxious when speaking a foreign language because they are experiencing foreign language anxiety. This anxiety can be divided into 3 categories: 'communication apprehension', 'fear of negative evaluation', and 'test anxiety'. Communication apprehension is related to language learners' shyness or fear when talking or listening to others while fear of negative evaluation can be described as learners' anxiousness towards people's judgement on their language ability, for instance their teachers or even friends. Test anxiety, on the other hand, is the fear of not being able to perform well in examinations or tests. Based on the researchers' observation, it was clear that in the beginning, the students' anxiety fell into these two categories: communication apprehension and 'fear of negative evaluation' because they 
were too shy to talk in front of the class even when introducing themselves for the first time. They were so nervous speaking in front of class and at the same time they were worried about making mistakes due to their lack of vocabulary and as well as low language proficiency.

However, the research shows that, exposing the students to a lot of speaking practices helped to reduce their speaking anxiety. In this research, in order to make the students talk, it was made mandatory for each student to speak in front of the class without any exception. This was done because the researchers wanted to make the classroom a conversational place where the students would be given a lot of opportunities to use the language and speak naturally in each lesson. This is proven to be a success because the students admitted a lot of speaking practices and being forced to speak in English helped them to overcome their fear and build up their confidence in speaking English.

(refer to Table 1). The study confirms that teacher's support and encouragement are needed in making sure all the students actively communicate during speaking lessons. If students are not encouraged to speak during language class, they would be afraid to utter the words of English even after several years of learning English (Kurniawati, 2013).

The findings of this study support the notion that, working in groups helped the students to be more composed and relaxed as compared to working on their own, moreover, students' worries and anxiousness are minimised (Alrabai, 2014; Awan, et al. 2010 ; Nagahasi, 2007). In this study, group work was highly emphasized. In fact, three out the five activities (fairy tale role-play, product advertising and group discussion) were done in groups. Even though, in the beginning the students were reluctant to speak, gradually through group work they began to talk. Group work enabled the students to work together, discussing and preparing the tasks and in a way practised cooperative learning. Working in a group provides a safe learning environment for low proficiency students because they know that they have peers that can support them and they are not alone in the learning process. Safe learning environment encourages students' active participation in class, increases the amount of student talk in the target language, decreases learning anxiety and improves learning retention. In fact, it motivates students to learn and enhance students' oral performances (Azizinezhad, Hashemi \& Darvishi, 2013). This learning method gives the opportunities for the students to use the language and learn from each other particularly from those who had slightly better language proficiency. Through group activities students would be able to understand each other's strengths and weaknesses in learning English. At the same time working together with their peers gives the students freedom to actively participate in group activities and use the language rather than just being passive listeners in a teachers' directed classroom (Olsen \& Kagan, 1992). 
This study also reveals that, to these low proficiency students, participating in the speaking activities helped to improve their speaking skills. Based on the researchers' observation, students' language skills improved because they were willing to speak English. All the five activities provide the students with the opportunities to use English for real purposes. Despite their low proficiency and shyness, as they worked together in groups they learnt to take part in discussion, interact with their friends and lecturer and express their ideas using English language. All these help to improve their speaking skills because they were given the chances to interact in different social contexts with different social roles (Celce-Murcia, 2000 cited in Kurniawati, 2013).

The findings were also in line with the idea that constructive feedback (from the lecturer) that was given after each lesson helped to improve students' speaking skills. Brookhart (2017) stated that a good feedback does not only contain the information that can be used by the students but it also helps the students to understand what needs to be done and why and understand where they are in their learning. Being able to identify their mistakes and learning to correct them helped to enhance students' understanding and improve their performance. Consequently, students will feel that they have control over their learning and are more motivated to learn (Bitchener \& Knoch, 2010; Brookhart, 2010; Moss \& Brookhart, 2012). Based on the researchers' observation, students took the verbal feedback that was given to them positively. They were able to recognise their own mistakes and tried to avoid repeating them. It was clear that the students were in control of their own learning and were motivated to learn and improve their speaking skills. Their motivation to learn helped to break the fear of speaking English and at the same time develop their selfconfidence. In short, feedback had helped the students to be aware of what needed to be improved and corrected in order to be able to communicate fluently and accurately.

\section{CONCLUSION}

This action research did not instantly improve students' language proficiency but it provided a platform for the students who were once very shy, lacked confidence and refused to use English to build up their self-confidence and improve their language skills. The main aim of this research was to make students speak and to break the barrier of shyness so that they would no longer be afraid of speaking English even though they were not fluent or accurate. Indeed, this study has proven that participating in these activities exposed the students to the real use of the language that helped to boost up their confidence in speaking, reduce their speaking anxiety, and improve their speaking skills. Thus, it can be concluded that these speaking activities have a very positive impact on students' confidence level which indirectly help to improve their speaking skills. Therefore, all these activities should be retained and continued 
with other groups of students in the future because the activities will definitely help to encourage students to speak confidently in English, particularly those who are too shy to speak the language.

\section{REFERENCES}

Alrabai, F. (2014). The Influence of Teachers' Anxiety-Reducing Strategies on Learners' Foreign Language Anxiety. Innovation in Language Learning and Teaching. 9 (2), 163-190

doi : https://doi.org/10.1080/17501229.2014.890203.

Awan, R. N., Azher, M., Anwar, M. N., \& Naz, A. (2010). An investigation of foreign language classroom anxiety and its relationship with students' achievement. Journal of College Teaching E Learning, 7,(11), 33-40.

Azizinezhad, M., Hashemi, M., \& Darvishi, S. (2013). Application of Cooperative Learning in EFL Classes to Enhance the Students' Language Learning. Procedia - Social and Behavioral Sciences 93. 138 - 141 . doi : 10.1016/j.sbspro.2013.09.166.

Bitchener, J. \& Knoch, U. (2010) Raising the linguistic accuracy level of advanced L2 writers with written corrective feedback. Journal of Second Language Writing, 19 (4), 207-217.

Brookhart, S. M. (2010). Formative assessment strategies for every classroom (2nd ed.). Alexandria, VA: ASCD.

Brookhart, S. M. (2017). How to give effective feedback to your students (2nd ed.). Alexandria, VA: ASCD.

Brown, H. D. (2000). Principles of language learning and teaching (4th ed.) White Plains, NY: Addison Wesley Longman, Inc.

Celce-Murcia, M. 2001. Teaching English as a Second or Foreign Language. Third Edition. New York: Heinle \& Heinle.

Crookall, D., \& Oxford, R. (1991). Dealing with anxiety: Some practical activities for language learners and teacher trainees. In E. K. Horwitz \& D. J. Young (Eds.), Language anxiety: From theory and research to classroom implications (pp.141-150). Englewood Cliffs, NJ: Prentice-Hall.

Dörnyei, Z., \& Ushioda, E. (2011). Teaching and researching motivation (2nd ed.). Harlow: Longman.

Horwitz, E. K., Horwitz, M. B., \& Cope, J. (1986). Foreign language classroom anxiety. The Modern Language Journal, 70(2), 125-132.

Kurniawati, A. (2013). Improving the students' self confidence in speaking practice by using role-play technique for the eighth grade students of SMP Muhammadyah 3 Yogyakarta (Degree thesis, State University of 
Yogyakarta, Indonesia). Retrieved from http://eprints.uny.ac.id/25689 Anna\%20Kurniawati\%2007202244041.pdf

Macintyre, P. D., \& Gardner, R. C. (1994). The subtle effects of language anxiety on cognitive processing in the second language. Language Learning, 44, 283-305.

Maulana, F., Ikhsanudin, I. \& Suhartono, L. (2020). Students' motivation to speak in a group discussion. Journal of English Education Program, 1(1) 50-58. Retrieved from

https://jurnal.untan.ac.id/index.php/JEEP/article/view/40025

Moss, C. M., \& Brookhart, S.M. (2012) Learning targets: helping students aim for understanding in today's lesson, Alexandria,VA: ASCD.

Musa, M. K., Hashim, M. Z. , Muhamad, S. \& Mohamed, R. (2013). Language learning anxiety: Malay undergraduates learning Japanese: Proceedings of $2^{\text {nd }}$ UPALS International Conference on Languages (pp.325-335).

Nagahashi, T. L. (2007). Techniques for reducing foreign language anxiety: results of successful intervention study. Bulletin of the Centre for Educational and Practice, 29, Akita University.

Noor, N. M., Aman, I., Mustaffa, R., \& Seong, T. K. (2010). Teacher's Verbal Feedback on Students' Response: A Malaysian ESL Classroom Discourse Analysis. Procedia Social and Behavioral Sciences, 398-405.

Pakpahan, M., Ikhsanudin, I. \& Sada, C. (2017). Factor affecting EFL students' unwillingness to communicate in campus. Jurnal Pendidikan dan Pembelajaran Khatulistiwa, 6(6), 3-11. Retrieved from https://jurnal.untan.ac.id/index.php/jpdpb/article/view/20271

Samperio, N. (2017). Discovering Students' Preference for Classroom Activities and Teachers' Activity Use. Colomb. Appl. Linguist. J., 19(1), 51-66.

Sullivan, C. (2016). Student preferences and expectations in an English classroom. Hermes-Ir, 52, 35-47.

Zhu, D. (2012). Using games to improve students' communicative ability. Journalof Language Teaching and Research, 3(4), 801-805.

\section{Authors' Brief CV}

Muriatul Khusmah Musa is a Senior Lecturer in Academy of Language Studies, Universiti Teknologi MARA Cawangan Pulau Pinang, Malaysia. She holds a Master's Degree in English Language Studies \& Methods from the University of Warwick, United Kingdom and BHsc.in English Language \& Literature from International Islamic University, Malaysia. Her research interests are in the fields of ELT and language \& communication. 
Rushita Ismail is a Senior lecturer at the Academy of Language Studies, Universiti Teknologi MARA Penang. She earned her PhD in Applied Linguistics at Universiti Sains Malaysia and her Masters in TESOL from the Central Connecticut State University, USA. Her research interests are in the areas of applied linguistics, second language acquisition, communication and blended learning. 